\title{
Implementasi Pembinaan Karakter Religius Berbasis Kearifan Local Maja Labo Dahu Pada Peserta Didik Sekolah Dasar di Kabupaten Bima
}

\author{
A. Gafar Hidayat ${ }^{1}$, Tati Haryati ${ }^{2}$ \\ STKIP Taman Siswa Bima \\ ${ }^{1}$ gafarhidayat@gmail.com, ${ }^{2}$ tatiharyati031@gmail.com
}

\begin{abstract}
Abstrak. Penulisan dilatar belakangi oleh krisis moral atau degradasi nilai moral yang melanda generasi usia sekolah terutama di sekolah dasar, sehingga perlu dicerati implementasi pembinaan karakter oleh guru dan sekolah. Tujuan penelitian ini untuk mendeskripsikan dan menganalisis implementasi atau pelaksanaan pembinaan karakter religius peserta didik, baik dalam pembelajaran maupun di luar pembelajaran yang berbasis nilai kearifan local maja labo dahu pada sekolah dasar di Kabupaten Bima. Penelitian ini, tergolong dalam penelitian deskriptif kualitatif. Teknik pengumpulan datanya dilakukan dengan wawancara, observasi, dan dokumentasi. Sedangkan teknik analisis menggunakan reduksi, penyajian, dan penarikan kesimpulan. Hasil penelitian menunjukan bahwa Pembinaan karakter religius berbasis nilai kearifan lokal maja labo dahu dalam pembelajaran, baik di kelas maupun di lingkungan sekolah, dilaksanakan dengar cara; (1) Membangun percakapan antara guru dengan peserta didik melalui tanya jawab tentang sebuah topik, untuk mewujudkan suasana yang hangat dan akrab, sehingga peserta didik dapat memahami secara secara utuh konsep nilai yang disampaikan oleh guru; (2) Menceritakan kisah yang inspiratif untuk dihayati oleh peserta didik dengan tujuan untuk membina karakter religiusnya, karena dalam kisah-kisah terdapat berbagai keteladanan dan pendidikan nilai; (3) Perumpamaan yang diberikan oleh guru pada saat pembelajaran dapat memotivasi peserta didik, untuk lebih baik lagi dari sebelumnya, terutama dalam membina karakter religius peserta didik melalui perumpamaan hal-hal yang akan terjadi dimasa mendatang apabila diri tidak diperbaiki hari ini; (4) Guru menjadikan dirinya sebagai teladan bagi peserta didik untuk membina karakter religiusnya di sekolah, keteladanan yang diberikan oleh guru pada peserta didik pada umumnya meniru kepribadian guru. Karena kebiasaan peserta didik untuk selalu meniru hal-hal yang ada disekitarnya, dan tidak perduli baik atau buruknya; (5) Pembiasan secara berulang-ulang, tentang konsep nilai dan gagasan yang berguna bagi pembinaan karakter religius peserta didik, agar hal baik yang dilakukan berulangulang dapat menjadi kebiasaan peserta didik.
\end{abstract}

Kata Kunci: Karakter Religius, Kearifan Local, Maja Labo Dahu

\section{PENDAHULUAN}

Kemajuan ilmu pengetahuan dan teknologi yang diciptakan oleh manusia membuka tabir perubahan secara berangsurangsur, dan mampu menggrogoti seluruh sendi kehidupan umat manusia. Peradaban manusia saat ini berada pada fase revolusi industry 4.0, hal itu dapat merubah cara pandang, gaya hidup, sikap atau prilaku dan hidup menjadi lebih efektif serta relative mudah dengan berbagai peralatan canggih yang sangat memanjakan manusia, namun dibalik kecanggihan tersebut terselubung dampak negatif, yang mampu memudarkan nilai-nilai kemanusia. Rasa saling menghargai dan membutuhkan satu dengan yang lain menjadi kurang, manusia lebih cenderung Jurnal Ilmu Sosial dan Pendidikan individualis dan gaya hidup bersifat konsumtif, serta manusia sudah tidak produktif lagi. Hal itu terjadi oleh karena dimanjakan oleh teknologi, sehingga manusia begitu terobsesi pada dunia.

Generasi penerus bangsa, yang masih rentan terhadap perubahan dan belum mampu menyikapi secara positif, setiap hal-hal baru yang dilihat, dan terjebak dalam pemahaman yang bersifat hedonik, maka tidak heran apabila banyak generasi yang terlibat prostitusi dan kenakalan remaja lainnya. Hal ini terjadi karena generasi kehilangan karakter dan identitas dirinya sebagai mahkluk yang berakal, sehingga menyebabkan terjadinya krisis moral. Bahkan masalah moral ini dapat melemahkan dunia pendidikan, karena 
kenyataannya sudah banyak kasus penyimpangan dan pelanggaran hukum yang dilakukan oleh anak usia sekolah (SD, SMP, SMA).

Fenomena social dalam kehidupan bermasyarakat yang terlihat akhir-akhir ini sudah sangat meresahkan, terutama dikalangan remaja usia sekolah, maraknya kasus kekerasan dalam menyelesaikan masalah yang menyebabkan terjadinya tawuran, meningkatnya perilaku yang tidak lazim, seperti narkoba, meminum alkohol, pelecehan seksual dan pemerkosaan, yang melibatkan anak usia sekolah. Hal tersebut menunjukan telah terjadi degradasi moral atau krisis moral yang melanda anak yang ditandai dengan menurunnya perilaku sopan santun, menurunnya perilaku kejujuran, menurunnya rasa kebersamaan, dan menurunnya rasa gotong royong di antara anggota masyarakat yang dapat memudarkan nilai-nilai karakter dalam diri anak.

Krisis moral yang dialami oleh peserta didik saat ini tidaklah sepatutnya menyalahkan lembaga pendidikan formal, sebab dibutuhkan peran lebih orang tua dalam mengawasi dan mendapingi pengetahuan peserta didik terhadap pendidikan nilai yang diperoleh dari lingkungan formal sangat diperlukan, karena orang tua yang lebih dekat dengan anak-anaknya, untuk memudahkan peserta didik mempraktekkan secara langsung pengetahuan yang diperoleh dari sekolah, baik lingkungan keluarga, lebih-lebih di tengah-tengah masyarakat.

Pendidikan karakter dapat mencerminkan budaya bangsa Indonesia yang heterogen, dalam membentuk pribadi manusia yang berkarakter baik dari sisi filosofis regional, maupun nasonal. Pendidikan memiliki peran penting untuk membentuk baik buruknya pribadi manusia dalam sudut pandang nilai dan agama. Oleh karena itu pemerintah mencanagkan program baru dalam dunia pendidikan tentang pendidikan bernilai karakter, dan hal itu tercermin melalui 18 nilai pendidikan karakter bangsa. Menyadari akan hal tersebut pemerintah sangat serius menangani bidang pendidikan, sebab dengan sistem pendidikan yang baik diharapkan muncul generasi penerus bangsa Jurnal Ilmu Sosial dan Pendidikan yang berkualitas dan mampu menyesuaikan diri untuk hidup bermasyarakat, berbangsa dan bernegara

Pembentukan karakter peserta didik tidak terlepas dari peran guru dan sekolah dalam merangsang perkembangan mental dan karakter peserta didik, hal itu dapat dilihat dari visi pembelajaran di sekolah. Sebagai lembaga yang bertanggung jawab terhadap kelangsungan proses pendidikan formal, sekolah memiliki program pembelajaran yang berbasis nilai, baik nilai kearifan lokal maupun pendidikan nilai karakter bangsa. Seperti yang diketahui sekolah selalu menyesuaikan dengan kebutuhan masyarakat sekitar akan konsep nilai yang diterapkan, tanpa mengurangi nilai karakter kebangsaan sebagaimana yang diterapkan dalam sistem pendidikan nasional.

Program pembentukan karakter peserta didik di sekolah, terutama yang berkaitan dengan karakter religius dapat diwujudkan melalui kegiatan intra kurikuler dan ekstra kurikuler seperti; melatih kedisilinana, membiasakan sikap saling menghormati, menjaga kebersihan, membaca Al-Qur'an atau yasinan bersama setiap hari jum'at sebelum dimulai KBM, pesantren kilat, muatan lokal, pramuka, senam bersama dan lain sebagainya. Hal tersebut dapat dilaksanakan sebagai program berkala dan berkesinambungan bagi peserta didik. Pihak sekolah juga membentuk kemintraan dengan wali murid untuk mensukseskan kegiatan pembentukan karakter yang berbasis nilai local.

Kabupaten Bima dikenal dengan masyarakat yang fanatik terhadap nilai dan norma. Sejak dinobatkan Abdul Kahir I, sebagai sultan pertama Bima pada tanggal 6 Juli 1640, saat itu mulai dikenalkan istilah nilai maja labo dahu, sebagai sumber nilai dan dasar kehidupan bagi suku Bima selama berabad-abad lamanya. maja labo dahu adalah kristalisasi nilai yang tumbuh dan bersemi dalam peradaban masyarakat Bima sejak lama. Konsepsi maja labo dahu yang menjadi falsafah hidup, pandangan hidup dan juga pegangan hidup masyarakat. Maja artinya malu sebagai landasan kepribadian untuk tidak melakukan hal-hal yang 
melanggar norma adat dan agama. Demikian pula dahu artinya takut sebagai landasan keimanan yang bermakna takut hanya kepada Tuhan yang Maha Esa. Nilai tersebut sebagai cerminan kepribadian dan keimanan dan sangat tepat dijadikan sebagai landasas pembinaan karakter religius peserta didik.

Menurut Tajib (1995) dalam bukunya Sejarah Dana Mbojo" maja labo dahu adalah pemandu kehidupan, bukan kehidupan yang memandu maja labo dahu. Karena falsafah itu berakar dari iman dan taqwa. Jika tidak dijalankan, akan berbahaya, dan jika dilaksanakan akan selamat. Hal ini tercermin dari ketekunan, keuletan dan semangat menuntut ilmu yang tinggi. Maja labo dahu mengandung nilai yang universal menyangkut tanggung jawab, melindungi dan mengayomi, tidak mementingkan diri sendiri dan kelompok, tidak rakus, keseimbangan hidup, perkataan dan perbuatan tidak bertentangan, serta mampu memimpin diri sendiri.

Maja labo dahu merupakan simbol bagi upaya kalangan agamawan dan adat Bima dalam menegakkan kebajikan di tengahtengah masyarakat. Dalam berbagai kajian mengenai maja labo dahu selalu menegakkan hal-hal yang berkaitan dengan Islam seperti; rasa takut kepada Tuhan apabila tidak melaksanakan ibadah yang diperintahkan, malu terhadap penyesalan apabila melakukan perbuatan buruk, jahat, dan menyimpang dari nilai-nilai Islam. maja labo dahu berhubungan langsung dengan makna keimanan, ketaqwaan, dan keikhlasan dalam menjalankan segala perintah Tuhan, berbuat baik sesama manusia serta perasaan malu dan takut pada diri sendiri apabila menyimpang dari nilai-nilai agama dan adat. Konsep nilai yang dirangkum maja labo dahu dalam proses sosialisasi kehidupan masyarakat Mbojo yaitu; (1) manusia mengadakan interaksi dengan dirinya; (2) wujud kehidupan manusia dengan manusia lainnya; (3) wujud kehidupan manusia dengan lingkungannya; (4) wujud kehidupan manusia dengan Tuhannya. Dalam diri masyarakat Bima yang maja labo dahu sesungguhnya tertanam nilai kejujuran, kesederhanaan, kerja keras dan keuletan.

Berdasarkan pengamatan penulis proses pembelajaran di sekolah dasar yang ada Jurnal Ilmu Sosial dan Pendidikan dikabupaten bima, rata-rata guru memulai pembelajaran dengan membaca doa, hal itu sudah mencerminkan pembinaan karakter religius, kemudian guru merangsang ingatan peserta didik tentang materi pelajaran pada pertemuan sebelumnya. Kemudian guru menjelaskan terkait materi yang diajarkan secara berpusat pada guru. Sampai berkhirnya pembelajaran guru dinilai kurang dalam memberikan contoh yang kontekstual yang berkaitan dengan penguatan nilai moral kepada peserta didik, guru hanya fokus pada penyampaian materi saja. Tugas guru tidak hanya sebagai pengajar, tapi yang lebih utama mendidik dan proses internalisasi nilai, karena peserta didik usia sekolah dasar yang harus diutamakan adalah pembinaan nilai moralnya, agar menjadi pribadi yang baik. Pada saat istrahat guru menegur peserta didik yang keluar dari halaman sekolah dengan nada yang sedikit keras, kemungkinan besar guru tersebut takut terjadi hal-hal yang tidak diinginkan pada peserta didik, karena menjadi tanggung jawab sekolah. Peserta didik berlari dan menyoraki gurunya sambil tertawa. Sikap peserta didik tersebut menunjukan tidak meghargai guru yang menegurnya dan sama sekali tidak memcerminkan nilai karakter yang baik, sedangkan masyarakat Bima sangat fanatik terhadap nilai dan norma. Pada kondisi ini sikap peserta didik tidak mencerminkan nilai kearifan lokal maja (malu) karna kesalahan yang diperbuat.

Mengingat nilai kearifan lokal maja labo dahu ini, berperan penting bagi kelangsungan hidup atau dijadikan sebagai identitas masyarakat Bima dalam menhadapi tatangan perubahan zaman dewasa ini, yang dijadikan sebagai pegangan dan pandangan hidup, perlu untuk dioptimalkan sedini mungkin dalam pembentukan karakter religius peserta didik. Terutama pada peserta didik Sekolah Dasar, dalam hal ini dibutuhkan peran guru profesional yang mengerti tentang pendidikan nilai, guna menyiapkan kematangan karakter religius peserta didik untuk menghadapi tantangan perubahan zaman.

Menurut Suwardani (2015) dalam tulisannya "Pewarisan Nilai-Nilai Kearifan Lokal untuk Memproteksi Masyarakat Bali 
dari Dampak Negatif Globalisasi” Penguatan dan pewarisan nilai-nilai kearifan lokal perlu dilakukan secara intensif pada generasi muda, mengingat gejala perubahan sosial budaya melaui arus gelombang globalisasi membawa perubahan cukup signifikan pada masyarakat, baik pada tataran surface structure (sikap dan pola-pola perilaku) dan deep structure (sistem nilai, pandangan hidup, filsafat dan keyakinan). Perubahan terjadi karena kontak budaya antar negara yang dimaknai adanya dialektika nilai-nilai baru dengan nilai-nilai lama yang saling mendominasi, yang memungkinkan terjadinya homogenisasi dan neoliberalisasi pada seluruh aspek kehidupan termasuk nilai-nilai budaya lokal yang selama ini menjadi pegangan masyarakat.

Penanganan dampak dominasi budaya global terhadap budaya lokal salah satunya dapat dilakukan melalui pengembangan kualitas sumber daya manusia, perluasan akses, dan relevansi pendidikan berbasis budaya dan kearifan lokal. Hal itu untuk memperkenalkan dan meningkatkan kecintaan masyarakat terhadap budaya lokal sekaligus meningkatkan kualitas dan daya saing masyarakat. Globalisasi dapat menciptakan banyak kesempatan untuk berbagi pengetahuan, teknologi, nilai-nilai sosial, dan norma perilaku yang mempromosikan perkembangan individu, organisasi dan masyarakat, oleh karena itu nilai kearifan lokal yang melakukan filterisasi terhadap ancaman perubahan zaman.

Pendidikan dan kebudayaan merupakan bagian yang tidak dapat dipisahkan, bagaikan dua sisi mata uang, yang apabila salah satu sisinya tidak ada atau hilang maka uang tersebut tidak dapat digunakan untuk membeli barang dan jasa. Begitupun pendidikan apabila tidak terdapat nilai filosofis budaya, maka tidak bisa ditentukan arah atau tujuan dalam pendidikan tersebut, keduannya satu kesatuan yang saling mendukung dan saling menguatkan. Kebudayaan menjadi dasar filsafat pendidikan sementara pendidikan menjadi penjaga utama, karena peran pendidikan membentuk orang untuk berbudaya, semakin tinggi tingkat pendidikan, maka akan menghasilkan budaya yang Jurnal Ilmu Sosial dan Pendidikan mampu menopang peradaban yang lebih maju.

Pendidikan pada dasarnya bukan sekedar transfer pengetahuan guru, tetapi mengajari peserta didik untuk tulus menghormati dirinya sendiri dan orang lain. Peserta didik juga dapat menghargai perbedaan, karena keberagaman dan perbedaan bukanlah sesuatu yang diperdebatkan, tetapi dirayakan sebagai bentuk kesempurnaan Tuhan yang menciptakan hambanya berangsa-bangsa dan bersuku-suku, sehingga konsep nilai kearifan lokal perlu diajarkan di sekolah sebagai dasar kajian nilai budaya, agar peserta didik dapat menghormati guru dan orang tua, serta saling mengasihi satu dengan yang lain sebagai sebuah ikatan dalam keberagaman.

Menurut Wibowo (2015) kearifan lokal bisa menjadi basis pendidikan karakter. Kearifan lokal teruji mampu bertahan dalam waktu yang lama, karena kearifan lokal; 1) mampu bertahan terhadap pengaruh budaya luar; 2) memiliki kemampuan mengakomodasi unsur-unsur budaya luar; mempunyai kemampuan mengintegrasikan unsur budaya luar kedalam budaya asli; 4) mempunyai kemampuan mengendalikan; dan 5) mampu memberi arah pada perkembangan budaya.

Sedangkan pandangan Sudarsana (2017) Pendidikan bebasis kearifan local merupakan pendidikan yang lebih didasarkan kepada pembudayaan nilai-nilai sosial keagamaan. Pendidikan ini akan memberikan pelajaran pada masyarakat untuk selalu dekat dalam situasi dan kondisi nyata yang dihadapi sekaligus dilakukan setiap hari. Dalam konteks ini pendidikan bebasis kearifan lokal mengajak kepada seluruh masyarakat untuk selalu mengedepankan nilai-nilai kearifan lokal dalam segala situasi/kondisi yang berlangsung dalam masayarakat tersebut.

Lebih lanjut pendapat Shufa (2018) dalam tulisannya "Pembelajaran Berbasis Kearifan Lokal di Sekolah Dasar; Sebuah Kerangka Konseptual" Pembelajaran berbasis kearifan lokal sangat penting untuk diterapkan guru dalam pembelajaran yang bermanfaat untuk meningkatkan pengetahuan dan pemahaman peserta didik serta sebagai media 
untuk penanaman rasa cinta terhadap kearifan lokal di daerahnya, penanaman karakter positif sesuai nilai luhur kearifan lokal serta membekali siswa untuk menghadapi segala permasalahan diluar sekolah. Langkah yang dapat dilakukan guru untuk menerapkan pembelajaran berbasis kearifan lokal yaitu; 1) mengidentifikasi keadaan dan potensi daerah; 2) menentukan fungsi dan tujuan; 3) menentukan kriteria dan bahan kajian; 4) menyusun rencana pembelajaran berbasis kearifan lokal.

Mengingat pentingnya pembinaan berbasis kearifan local, sekolah dan guru dapat merancang dan mengembangkan pembelajaran berbasis kearifan local dengan melibatkan orang tua atau lewat pemberdayaan komite sekolah dan masyarakat, dalam upaya pembinaan karakter peserta didik yang bersumber dari nilai kearifan local maja labo dahu perlu dilibatkan dalam perencanaan, pelaksanaan, implementasi dan evaluasi sesuai peran dan bidangnya masing-masing.

Nilai-nilai yang terkandung dalam maja labo dahu yang dapat digunakan untuk membina karakter religius peserta didik sebagai berikut; (1) Nilai Spiritual yaitu, konsep nilai ini menjeskan tentang tata cara membangung hubungan dengan pencipta, alam/lingkungan dan diri sendiri, sebagai bentuk pengakuan akan adanya pencipta dan selalu memelihara hasil ciptaannya, untuk mewujudkan rasa syukur yang mendalam pada diri sendiri, sehingga taat untuk beribadah. Konsep nilai spiritial sangat cocok untuk membina karakter religius peserta didik, agar menjadi lebih taat dan selalu merasa bersyukur atas segala capaian dan yang ada, baik dalam diri maupun di lingkungan sekitar; (2) Nilai Sosial yaitu, konsep maja menunjukan rasa perduli, empati, simpati terhadap sesama, menghormati yang lebih tua, sikap rendah hati, menjaga sikap, beretika dalam berbicara dan bertindak, serta menjelaskan tata cara berhubungan atau berinteraksi pada sesama ciptaan Tuhan, tidak hanya dengan sesama manusia, juga dengan lingkungan dan mahluk ciptaan lainnya. Konsep nilai sosial yang dimiliki nilai maja sangat tepat dalam Jurnal Ilmu Sosial dan Pendidikan membina karakter religius peserta didik, sebagai karakter asli dou mbojo; (3) Nilai Disiplin yaitu, nilai maja labo dahu juga mengandung makna patuh untuk menjalankan segala atauran yang berlaku di tengah-tengah masyarakat yang disepakati bersama dan tunduk terhadap larangan-larangan yang dianggap oleh masyarakat tidak lazim, sehingga menujukan sikap yang taat dan patuh pada aturan yang tersirat dan tersurat; (4) Nilai Jujur yaitu, maja labo dahu memperlihatkan makna nilai jujur pada konsep dahu/takut, apabila tidak jujur, maka akan mendapat sanksi dosa dimata Tuhan sebagai konsekwensi dari sikap ketidak jujurannya. Konsep nilai takut dapat menjadikan manusia yang jujur dan dapat dipercaya; (5) Nilai Tanggung jawab yaitu, nilai ini juga terkandung dalam maja labo dahu dimana untuk mewujudkan rasa malu dan takut, paling tidak dalam menjalakan tugas atau wewenang dengan penuh amanah sebagai kewajiban, jika tidak amanah maka akan hilang rasa malunya terhadap sesama dan takutnya kepada pencipta. Sehingga nilai tanggung jawab juga terkandung dalam praktek maja labo dahu.

Pendidikan karakter terbangun atas pengetahuan tentang nilai-nilai moral yang membentuk sikap, dan watak seseorang, sehingga tercermin pada tindakan. Konsep nilai dapat mempengaruhi tindakan seseorang dalam kehidupannya sehari-hari, karena pencapaian suatu kebenaran yang hakiki dalam membangun cara pandang terhadap sesuatu, didasari oleh pengetahuan tentang nilai. Jadi karakter seseorang akan terbentuk dengan baik, apabila pengetahuan nilai-nilai moral yang baik, sehingga sikap, prilaku dan watak seseorang akan terbentuk sebagai karakter yang baik.

System penanaman nilai-nilai karakter kepada peserta didik yang meliputi komponen pengetahuan, kesadaran atau kemauan, dan tindakan untuk melaksanakan nilai-nilai tersebut, baik terhadap Tuhan diri sendiri, sesama, lingkungan, maupun kebangsaan sehingga menjadi manusia yang baik. Oleh karena itu pendidikan karakter di sekolah, harus melibatkan semua komponen yang berfungsi membentuk karakter, termasuk 
komponen-komponen pendidikan itu sendiri, yaitu isi kurikulum, proses pembelajaran dan penilaian, kualitas hubungan, penanganan atau pengelolaan mata pelajaran, pengelolaan sekolah, pelaksanaan aktivitas, pemberdayaan sarana dan prasarana lingkungan sekolah.

Perkembangan karakter pada setiap individu dipengaruhi oleh faktor bawaan (nature) dan faktor lingkungan (nurture). Setiap anak memiliki potensi bawaan yang termanifestasikan setelah dilahirkan, termasuk potensi yang terkait dengan karakter atau nilai-nilai kebajikan. Namun bila potensi ini, tidak diikuti dengan pendidikan dan sosialisasi setelah anak dilahirkan, maka anak tersebut dapat berubah menjadi tidak manusiawi bahkan lebih buruk lagi. Oleh karena itu sosialisasi dan pendidikan anak yang berkaitan dengan nilai-nilai kebajikan, baik di keluarga, sekolah, maupun lingkungan yang lebih luas sangat penting dalam pembentukan karakter seorang anak (Latifah, 2010).

Pembinaan karakter peserta didik perlu untuk dilakukan, mengingat arti penting karakter yang baik bagi kehidupan peserta didik kedepannya, oleh karena itu peran sekolah sebagai pijakan dasar penyelenggara pendidikan karakter haruslah maksimal dan memenuhi standar mutu untuk mencapai tujuan tertentu. Pertumbuhan karakter yang baik akan mendorong peserta didik tumbuh bersama komitmen untuk melakukan berbagai hal yang terbaik dan melakukan segalanya dengan benar serta memiliki tujuan hidup yang mengarah kepada hal-hal baik pula, oleh karena itu dibutuhkan peran penting seorang guru dalam menagarahkan pendidikan nilai moral pada peserta didik.

Karakter berkembang berdasarkan kebutuhan untuk mengganti insting yang hilang ketika manusia berkembang tahap demi tahap. Karakter membuat seseorang mampu berfungsi di dunia tanpa harus memikirkan apa yang harus dikerjakan. Artinya karakter manusia berkembang dan dibentuk oleh pengaturan sosial. Masyarakat membentuk karakter melalui pendidikan dan orang tua, agar anak bersedia bertingkah laku seperti yang dikehendaki masyarakat (Zubaedi, 2011).

Jurnal Ilmu Sosial dan Pendidikan
Menurut Lickona (2013) dalam pengembangan karakter yang baik terdapat tiga komponen yang saling mempengaruhi satu dengan yang lainya, yaitu pengetahuan moral, perasaan moral dan tindakan moral; (1) Pengetahun Moral yaitu, pengetahuan akan nilai-nilai moral, dapat memunculkan kesadaran, pengambilan perspektif, penalaran, pengambilan keputusan dan pengetahuan diri. Beberapa komponen ini terlibat dalam konsep pengetahuan yang dapat memeberikan wawasan kepada manusia sebagai petunjuk dalam menuntun hidupnya dimasa mendatang; (2) Perasaan Moral yaitu, sisi emosional karakter memiliki peran yang sangat penting dalam memahami, hakikat fitrah tentang hal-hal yang benar, karena berkaitan dengan hati nurani, penghargaan diri, empati, mencintai kebaikan, kontrol diri, dan kerendahan hati. Hal ini dapat dikategorikan sebagai cara seseorang merenpon atau menerima sesuatu, dari luar dirinya, dengan memberikan pertanyaan besar dalam hatinya, tentang hal-hal yang diterima tersebut, baik atau tidaknya; (3) Tindakan Moral yaitu, tindakan adalah produk dua bagian karakter lainnya yang berpengaruh pada tindakan, baik dan benarnya tindakan seseorang ditentukan oleh kedua konsep sebelumnya. Dalam hal ini meliputi Kompetensi, kehendak dan kebiasaan. Tindakan seseorang tergantung dari apa yang diketahui sebelumnya, yang bisa dijadikan kompetensi atau keahlian dalam bidang tertentu dan harus didukung oleh kemauan atau kehendak untuk melakukannya, apabila hal itu dilakukan secara berulang-ulang, maka akan menjadi kebiasaan.

Sedangkan pandangan Gunawan (2017) ada beberapa metode yang harus dilakukan dalam mengembangkan pendidikan karakter, yaitu; (1) Metode Percakapan yaitu percakapan silih berganti antara dua pihak atau lebih melalui tanya jawab tentang sebuah topik, dan dengan sengaja diarahkan pada satu tujuan yang dikehendaki. Dalam proses ini memiliki dampak yang sangat mendalam terhadap jiwa pendengar atau pembaca yang mengikuti topik percakapan dengan seksama dan penuh perhatian; Metode Cerita yaitu, dalam pelaksanan pendidikan karakter 
disekolah kisah sebagai metode pendukung pelaksanaan pendidikan memiliki peran yang sangat penting, karena dalam kisah-kisah terdapat berbagai keteladanan dan edukasi; (3) Metode Perumpamaan yaitu, metode ini dapat digunakan oleh para guru dalam mengajari peserta didiknya terutama dalam menanamkan karakter kepada peserta didik melalui perumpamaan hal-hal yang akan terjadi dimasa mendatang apabila diri tidak diperbaiki hari ini; (4) Metode Keteladanan yaitu, dalam penanaman karakter bagi peserta didik di sekolah, keteladanan merupakan metode yang lebih efektif dan efisien, karena peserta didik pada umumnya cenderung mendalami atau meniru guru dan pendidiknya. Hal itu berangkat dari psikologi siswa yang suka meniru, tidak saja yang baik bahkan yang jeleknya pun ditiru; (5) Metode Pembiasaan yaitu, pembiasan merupakan sesuatu yang disengaja dilakukan secara berulang-ulang agar sesuatu yang dilakukan dapat menjadi kebiasaan. Hal ini sangat efektif dalam pembinaan karakter dan kepribadian anak. Apabila pembiasaan dilakukan secara terus menerus dan berulang kali tanpa terputus, maka secara otomatis akan menjadi kebiasaan.

Pengembangan karakter dalam pendidikan merupakan keterkaitan antara komponen-komponen karakter yang mengandung nilai-nilai moral dan perilaku yang dapat dilakukan untuk bertindak secara bertahap dan saling berhubungan antara pengetahuan nilai-nilai moral dengan sikap atau emosi yang kuat untuk melaksanakan perannya sebagai individu yang baik terhadap keimanannya kepada Tuhan, mengenal tentang dirinya, berguna bagi keluarga, lingkungan masyarakat, bangsa dan negara.

Karakter religius merupakan sikap dan prilaku individu yang patuh dalam melaksanakan ajaran agama yang dianutnya, toleran terhadap pelaksanaan ibadah agama lain dan hidup rukun dengan pemeluk agama lain. Sebagai warga negara Indonesia yang berdasarkan pancasila, dimana semua warga negara wajib memeluk salah satu agama yang sah dan diakui oleh negara, sehingga dalam memeluk suatu agama harus dibarengi dengan mengamalkan semua ajaran agama yang Jurnal Ilmu Sosial dan Pendidikan dianutnya. Karakter religius sangat dibutuhkan oleh peserta didik dalam menghadapi tantangan perubahan zaman yang mengarah pada degradasi nilai akhlak dan moral, oleh karena itu diharapkan mampu berprilaku baik yang didasarkan pada ketentuan norma dan agama.

Mengajarkan nilai-nilai keagamaan pada peserta didik sebenarnya bukanlah persoalan yang sulit, karena sesungguhnya nilai keagamaan pada dasarnya melekat dalam norma dan praktek kehidupan seharihari. Artinya ketika peserta didik diajarkan tentang norma kehidupan yang baik, secara tidak langsung kita sedang menanamkan nilai-nilai religius, sehingga dengan pengetahuan nilai moral yang baik yang berakar pada norma agama dapat dijadikan petunjuk bagi sikap dan perilaku peserta didik (Wibowo dan Gunawan 2015).

Nilai religius merupakan akhlak yang mulia sebagai salah satu faktor internal siswa yang mempunyai andil dalam prestasi belajar. Siswa pada hakikatnya merupakan masa transisi dari anak-anak menuju remaja. Pada masa ini dimulai dari pembentukan dan perkembangan sistem moral yang sejalan dengan pengalaman agama. Dalam perkembangan lebih lanjut pengalaman kehidupan beragama sedikit demi sedikit semakin mantap sebagai suatu unit yang otonom yang merupakan organisasi yang disebut "nilai-nilai religi" sebagai hasil peranan fungsi kejiwaan terutama motivasi, emosi, dan intelegensi (Muhaimin, 2009: 111).

Mengingat pentingnya penumbuhan karakter religius disekolah guru perlu mengajarkan sejak dini terutama pada peserta didik sekolah dasar, tentang pengetahuan norma agama, untuk membatasi tindakan yang bersifat amoral yang dilakukan oleh peserta didik, sehingga dapat menghormati guru, mengerti tentang pola berperilaku dengan teman sebaya dan menghormati orang tua. Bahkan perlu diajarkan bagaimana tata cara berkomunikasi dengan orang lain, sehingga hal tersebut sejalan dengan konsep penidikan nilai karakter religius.

Menurut Khotimah (2016) dalam tulisannya "Model Pendidikan Karakter 
Religius di SD IT Qurrota A'yun Ponorogo" karakter religius berfungsi untuk membangun kesadaran anak tentang adanya Tuhan dan hubungannya dengan pencipta. Dalam konteks kurikulum sekolahan, pendidikan karakter religius diperlukan untuk menghantarkan peserta didik menjadi insan yang beriman dan bertaqwa, berakhlak mulia, tertib dan disiplin sesuai dengan peraturan yang ada, sopan santun terhadap guru dan orang tua, serta peduli terhadap lingkungannya. Karakter religius dapat dikembangkan melalui; 1) nilai agama Islam; 2) struktur Visi dan Misi, Kurikulum dan RPP, dan draf budaya religius sekolah; 3) melalui Kegiatan Belajar Mengajar (KBM), pelaksanaan budaya sekolah dengan metode keteladanan dan pembiasaan, dan memalui kegiatan pengembangan diri.

Nilai karakter religius merupakan dasar dan arah konsep prilaku peserta didik dalam memberikan tanggapan, reaksi, pengolahan dan penyesuaian diri terhadap rangsangan yang datang dari luar, sehingga semua tingkah laku dalam kehidupan peserta didik seperti; belajar, bergaul dan bermasyarakat diwarnai oleh sistem nilai-nilai religiusnya. Oleh karena itu peserta didik yang tinggi nilai-nilai religiusnya maka besar kemungkinan, akan menjadi peserta didik yang baik, rajin belajar dan taat pada tata tertib sekolah. Peserta didik tersebut akan belajar dengan penuh kesadaran tanpa ada unsur paksaan, sebab belajar merupakan salah satu kewajiban dari ajaran agama. Adapun tujuan penelitian ini untuk mendeskripsikan dan menganalisis pelaksanaan pembinaan karakter religius peserta didik, baik dalam pembelajaran maupun di luar pembelajaran yang berbasis nilai kearifan local maja labo dahu pada sekolah dasar di Kabupaten Bima.

\section{METODE PENELITIAN}

Penelitian ini, tergolong dalam penelitian deskriptif kualitatif. Penelitian kualitatif adalah penelitian yang menggunakan pendekatan naturalistik untuk memahami fenomena dalam suatu latar yang berkonteks khusus. Prosedur analisis yang tidak menggunakan analisis statistik atau cara kuantifikasi sejinisnya. Penelitian kualitatif Jurnal Ilmu Sosial dan Pendidikan datanya berupa uraian tertulis, uraian yang diperoleh dari informan, dan perilaku subjek yang diamati. Penelitian ini menunjuk pada prosedur penelitian yang menghasilkan data deskriptif, yakni apa yang dilakukan secara fundamental dan dituturkan informan, baik lisan maupun tulisan.

\section{Subjek Penelitian}

Subjek penelitian dipilih secara purposive atau dengan pertimbangan, kemampuan informan dalam menyampaikan informasi permasalahan yang diteliti. Dalam hal ini yang dianggap memenuhi syarat mengetahui substansi implementasi pembinaan karakter religius berbasis nilai kearifan lokal maja labo $d a h u$, yaitu guru dan Kepala Sekolah SDN di wilayah Kabupaten Bima. Sehingga penentuan sampel dalam penelitian kualitatif dilakukan saat peneliti mulai memasuki lokasi penelitian dan selama penelitian berlangsung.

\section{Teknik Pengumpulan Data Wawancara}

Berdialog langsung dengan informan dengan mengajukan pertanyaan yang telah disusun berdasarkan pedoman wawancara. Dalam hal ini peneliti hanya melemparkan secara garis besar pada setiap item kemudian peneliti mengembangkan pertanyaan tersebut ketika proses wawancara berlangsung.

\section{Observasi}

Mengamati tingkah laku guru dan peserta didik dalam keadaan alamiah, tetapi peneliti tidak melakukan partisipasi terhadap kegiatan di lingkungan yang diamati. artinya peneliti bertindak hanya sebagai pengamat, tidak ikut terlibat dalam kegiatan tersebut.

\section{Dokumentasi}

Teknik pengumpulan data dengan menghimpun dan menganalisis dokumendokumen berupa catatan peristiwa yang sudah berlalu dapat berupa tulisan, gambar atau karya non monumental dianalisis, sehingga membentuk suatu hasil kajian yang sistematis, padu dan utuh. 


\section{Teknik Analisis Data}

\section{Reduksi Data (Data Reduction)}

Menhimpun data hasil wawancara, yang dikemukakan oleh guru, peserta didik, dan kepala sekolah. Kemudian direduksi atau merangkum semua hasil wawancara, observasi dan telah dokumentasi dan mengambil hal pokok, yang difokuskan pada permasalahan penelitian

\section{Penyajian Data (Data Display)}

Menyajikan data tersebut dalam bentuk narasi, artinya setiap fenomena yang terjadi apapun ditemukan, peneliti menarasikan dan memberikan interpretasi terhadap fenomena-fenomena tersebut. Hal ini dilakukan untuk memberikan pemahaman kepada peneliti dengan fenomena-fenomena yang terjadi.

\section{Penarikan Kesimpulan.}

Penarikan kesimpulan, yaitu data hasil penyajian dengan melakukan penafsiran data penelitian maka langkah selanjutnya yang dilakukan adalah dengan menarik kesimpulan dari hasil penelitian.

\section{HASIL DAN PEMBAHASAN}

Masyarakat Bima dikenal sangat fanatik terhadap nilai-nilai budaya dan agama, namun hal ini sudah mulai tergerus oleh perubahan zaman yang terjadi begitu cepat dan mempengaruhi berbagai sendi kehidupan masyarakat. Sampai saat ini, nilai local budaya yang diwariskan oleh para leluhur dilestarikan sampai saat ini oleh pemerintah daerah, seperti; nilai maja labo dahu (malu dan takut), ngaha aina ngoho (boleh makan jangan babat hutan), kone seke wati sampakena (sedikit tidak masih bisa) nggahi rawi pahu (ucapan sesuai perbuatan) dan masih banyak lagi nilai-nilai lokal lainnya. Pemerintah daerah kabupaten Bima saat ini memiliki visi pembangunan yang diadopsi dari nilai maja labo dahu, dan diwujudkan dalam bentuk RAMAH (Religius, Aman, Makmur, Amanah dan Handal) dan diimplementasikan pada setiap satuan unit dinas yang membantu pemerintah dalam menjalankan tugasnya, salah satu contoh, setiap desa di instruksikan untuk mewujudkan Bima RAMAH, dengan diadakan magrib Jurnal Ilmu Sosial dan Pendidikan mengaji, baik dilakukan dimasjid-masjid maupun rumah-rumah warga, sedangkan di sekolah pada semua jenjang pendidikan (SD, SMP, \& SMA) diadakan secara rutin pada setiap hari jum'at yasinan bersama dan bersyalawat, serta dilanjutkan dengan ceramah agama untuk peserta didik.

Nilai maja labo dahu bukan sekedar istilah falsafat budaya tradisional, tapi bagi masyarakat Bima nilai ini sudah mendarah daging, dan terus dilestarikan melalui membina hubungan baik dengan sesama warga masyarakat dan menanamkan rasa takut hanya kepada sang pencipta. Dalam hal ini, sangat erat kaitannya dengan nilai karakter religius, sehingga nilai maja labo dahu sangat cocok untuk membina dan memperkuat karakter religius yang dimiliki oleh generasi penerus, terutama peserta didik. konsep nilai ini, memiliki banyak tafsir, namun tetap dalam satu makna religiusnya, ada sebahagian kalangan yang memahaminya secara praktis dan bersifat kondisional dan dapat diadaptasi dalam kondisi apapun. Untuk itu nilai ini selalu disampaikan oleh guru kepada peserta didik pada semua jenjang pendidikan yang ada di Bima, baik secara terstruktur maupun tidak, karena nilai ini sudah terekam secara refleks dalam hal membina moral peserta didik.

Pelaksanaan pembinaan karakter oleh guru dan sekolah yang ada di Kabupaten Bima, secara dominan menggunakan pendekatan nilai kearifan lokal maja labo dahu sebagai basis penggalian nilai-nilai moral dan karakter, untuk mengatasi krisis moral yang melanda peserta didik, oleh karena itu guru profesional memahami konsep nilai, maja labo dahu sebagai basis pembelajaran di luar kelas, dengan memberi pengarahan tentang nilai-nila pada saat peserta didik berada di lingkungan sekolah, serta menceritakan kisah-kisah motivasi teladan tokoh-tokoh lokal yang mengamalkan konsep nilai tersebut kepada peserta didik dan guru langsung memantau cara peserta didik bergaul dengan teman sebayanya, kemudian diberikan arahan tentang cara bertutur kata dan berprilaku baik, agar karakter religius peserta didik dapat dibina melalui nilai kearifan lokal maja labo dahu. 
Upaya yang dilakukan oleh guru, dan sekolah dalam membina karakter religius peserta didik, dilakukan secara terus menerus, setiap peserta didik datang dan pulang sekolah, hal itu dibiasakan kepada peserta didik untuk selalu membudayakan (3S) di lingkungan sekolah, yaitu; senyum, salam dan sapa. Dalam konteks pemahaman ini peserta didik selalu disuruh untuk mengucapkan salam, ketika melihat guru atau pegawai yang berada dilingkungan sekolah, dan diarahkan selalu meyalimi guru dengan cara mencium tangan guru dan selalu mendengarkan perkataan guru untuk perduli pada lingkungan sekolah serta menjaga kebersihannya.

Membina karakter religius peserta didik di luar kelas sangat diperlukan untuk setiap peserta didik untuk menjadi lebih baik, terutama dalam menjaga nilai-nilai kekayaan lokal sebagai cerminan kepribadian, sebagai warga masyarakat yang lebih baik. Dalam membina sikap dan perilaku peserta didik di lingkungan sekolah guru dan sekolah melibatkan semua lembaga yang berhubungan dengan sekolah untuk memaksimalkan pelaksanaan program pembinaan karakter peserta didik, karena membina karakter religius memegang peran penting untuk kelangsungan hidup generasi dimassa mendatang, untuk itu nilai maja labo dahu perlu dimaksimalkan dan ditindaklanjuti pengetahuan moral yang sudah disampaiakan oleh guru dalam kelas dan diimplementasikan pada tindakan nyata, serta didukung oleh keluarga, dan masyarakat. Sehingga guru profesional punya peran penting dalam meningkatkan karakter religius yang berbasis nilai maja labo dahu di sekolah.

Guru profesional yang ada di SDN Sila menggunakan pendekatan nilai-nilai lokal dalam mendidik peserta didik, oleh karena itu guru dengan penuh dedikasi dan loyalitas berusaha membimbing dan membina anak didik agar di massa mendatang menjadi orang yang berguna bagi nusa dan bangsa. Hal itu tidak hanya sekedar disampaikan secara lisan pada saat pembelajaran berlangsung akan tetapi juga dilaksankan melalui kegiatankegiatan di lingkungan sekolah. Dari besarnya tanggung jawab guru terhadap pendidikan moral peserta didik, guru setiap saat Jurnal Ilmu Sosial dan Pendidikan meluangkan waktu untuk membina karakter religius peserta didik, apabila ada peserta didik yang melakukan hal-hal yang kurang baik, harus dengan sabar dan bijaksana, dalam memberikan nasihat tentang cara bersikap dan bertingkah laku agar tidak menyinggung perasaan orang lain.

Secara garis besar pembinaan karakter religius peserta didik berbasis nilai kearifan lokal maja labo dahu di lingkungan sekolah, dilaksanakan dalam berbagai bentuk, diantaranya; (1) membina dengan mengarahkan sikap dan perilaku peserta didik di lingkungan sekolah melalui nilai maja untuk menjadi pribadi yang lebih baik; (2) Peserta didik dibiasakan untuk membudayakan 3S (senyum, salam, sapa) di lingkungan sekolah, dan merawat kebersihan lingkungan sekolah untuk membina karakter religiusnya; (3) Pembinan karakter religius peserta didik dilakukan dengan kegiatan kerohanian, seperti yasinan bersama setiap hari jum'at, membiasakan sholat dzuhur secara berjamaah sebelum pulang sekolah, kegiatan pesantren kilat, dan disetiap kesempatan selalu ditanamkan maja labo dahu; (4) Diadakan kegiatan penunjang di luar sekolah, seperti; pramuka, kemah bersama, lintas alam, event-event anatara sekolah, dan lain sebagainya, untuk menguatkan peserta didik, tentang pentingnya kebersamaan dan selalu menjaga hubungan baik dengan sesama.

Nilai-nilai yang terkandung dalam maja labo dahu yang digunakan oleh guru profesional dalam membina karakter religius peserta didik sebagai berikut:

\section{Nilai Spiritual}

Konsep nilai ini menjeskan tentang tata cara membangung hubungan dengan pencipta, alam/lingkungan dan diri sendiri, sebagai bentuk pengakuan akan adanya pencipta dan selalu memelihara hasil ciptaannya, untuk mewujudkan rasa syukur yang mendalam pada diri sendiri, sehingga taat untuk beribadah. Konsep nilai spiritial sangat cocok untuk membina karakter religius peserta didik, agar menjadi lebih taat dan selalu merasa bersyukur atas segala capaian dan yang ada, baik dalam diri maupun di lingkungan sekitar. 


\section{Nilai Sosial}

Konsep maja menunjukan rasa perduli, empati, simpati terhadap sesama, menghormati yang lebih tua, sikap rendah hati, menjaga sikap, beretika dalam berbicara dan bertindak, serta menjelaskan tata cara berhubungan atau berinteraksi pada sesama ciptaan Tuhan, tidak hanya dengan sesama manusia, juga dengan lingkungan dan mahluk ciptaan lainnya. Konsep nilai sosial yang dimiliki nilai maja sangat tepat dalam membina karakter religius peserta didik, sebagai karakter asli dou mbojo.

\section{Nilai Disiplin}

Nilai maja labo dahu juga mengandung makna patuh untuk menjalankan segala atauran yang berlaku di tengah-tengah masyarakat yang disepakati bersama dan tunduk terhadap larangan-larangan yang dianggap oleh masyarakat tidak lazim, sehingga menujukan sikap yang taat dan patuh pada aturan yang tersirat dan tersurat.

\section{Nilai Kejujuran}

Maja labo dahu memperlihatkan makna nilai jujur pada konsep dahu/takut, apabila tidak jujur, maka akan mendapat sanksi dosa dimata Tuhan sebagai konsekwensi dari sikap ketidak jujurannya. Konsep nilai takut dapat menjadikan manusia yang jujur dan dapat dipercaya.

\section{Nilai Tanggung Jawab}

Nilai ini juga terkandung dalam maja labo dahu dimana untuk mewujudkan rasa malu dan takut, paling tidak dalam menjalakan tugas atau wewenang dengan penuh amanah sebagai kewajiban, jika tidak amanah maka akan hilang rasa malunya terhadap sesama dan takutnya kepada pencipta. Sehingga nilai tanggung jawab juga terkandung dalam praktek maja labo dahu.

Adapun pembinaan karakter dengan mengintegrasikan nilai kearifan lokal maja labo dahu dalam pembelajaran, baik di kelas maupun di lingkungan sekolah, yaitu sebagai berikut:

\section{Membangun Percakapan}

Percakapan antara guru dengan peserta didik melalui tanya jawab tentang sebuah topik, untuk mewujudkan suasana yang hangat dan akrab, tanpa rasa takut dalam diri peserta didik untuk mengutarakan Jurnal Ilmu Sosial dan Pendidikan pendapatnya yang diarahkan pada satu tujuan yang yang hendak dicapai. Sehingga peserta didik dapat memahami secara secara utuh konsep nilai yang disampaikan oleh guru.

\section{Bercerita}

Guru menceritakan kisah yang inspiratif untuk dihayati oleh peserta didik dengan tujuan untuk membina karakter religiusnya, karena dalam kisah-kisah terdapat berbagai keteladanan dan pendidikan nilai.

\section{Perumpamaan}

Perumpamaan yang diberikan oleh guru pada saat pembelajaran dapat memotivasi peserta didik, untuk lebih baik lagi dari sebelumnya, terutama dalam membina karakter religius peserta didik melalui perumpamaan hal-hal yang akan terjadi dimasa mendatang apabila diri tidak diperbaiki hari ini.

\section{Keteladanan}

Guru menjadikan dirinya sebagai teladan bagi peserta didik untuk membina karakter religiusnya di sekolah, keteladanan yang diberikan oleh guru pada peserta didik pada umumnya meniru kepribadian guru. Karena kebiasaan peserta didik untuk selalu meniru hal-hal yang ada disekitarnya, dan tidak perduli baik atau buruknya.

\section{Pembiasaan}

Guru melakukan pembiasan secara berulang-ulang, tentang konsep nilai dan gagasan yang berguna bagi pembinaan karakter religius peserta didik, agar hal baik yang dilakukan berulang-ulang dapat menjadi kebiasaan peserta didik.

Hasil penelitian ini, sejalan dengan pandangan Thomas Lickona (2013) tentang pembentukan karakter yang baik dalam diri peserta didik, melalui tiga komponen utama yang harus dibina oleh guru profesional yaitu pengetahuan moral, perasaan moral dan tindakan moral, dengan penjelasan sebagai berikut:

\section{Aspek Pengetahuan Moral}

Pada tahap ini guru profesional memberikan pengetahuan moral kepada peserta didik yang mencerminkan nilai-nilai kearifan lokal maja labo dahu kepada peserta didik secara terus menerus dengan mengintergrasikan pada pembelajaran dalam kelas dan lingkungan sekolah, untuk 
mewujudkan kesadaran moral peserta didik tentang pentingnya pemahaman nilai-nilai luhur budaya sebagai cerminan spritual dalam membina karakter religius. Pada kontek pemahaman guru profesional menjelaskan nilai-nilai lokal maja labo dahu dengan bahasa yang sederhana dan menggunakan istilah-istilah lokal untuk memudahkan peserta didik memahami nilai-nilai moral, seperti; spiritual, sosial, jujur, disiplin dan tanggung jawab yang terkandung dalam nilai maja labo dahu, sehingga dapat memberikan tanggapan atau pengambilan perspektif untuk melihat seracara menyeluruh pada khalayak umum tentang cerminan nilai, untuk membuat keputusan terhadap pelajaran apa yang ada diambil dari pengetahuan tersebut, sehingga dari kesadaran moral yang dimiliki, mampu memahami diri sendiri dan orang lain, untuk menentukan sesuatu yang benar pada konteks sikap dan perilaku, yang mengarah pada karakter religius.

\section{Perasaan Moral}

Pada tahap ini kegiatan pembinaan, menyentuh sisi nurani peserta didik dari pemahaman yang sudah diberikan tentang nilai spiritual, sosial, jujur, disiplin dan tanggung jawab, yang terkandung dalam maja labo dahu serta peran pentingnya bagi kehidupan masa mendatang terutama dalam menghadapi tantangan perubahan zaman, untuk mengarahkan lebih lanjut pembinaan karakter religius, dengan cara memotivasi, menanamkan sikap kepedulian terhadap sesuatu yang dianggap penting, agar tertanam kuat dalam hati dan pikiran peserta didik, tentang nilai tersebut, sehingga dapat dilakukan dengan niat yang kuat. Melalui percakapan, perumpamaan, bercerita, keteladanan dan pembiasaan, sehingga peserta didik respek pada motivasi yang diberikan dan tertanam dalam diri peserta didik untuk selalu mencintai kebaikan-kebaikan, dari setiap makna nilai yang terkandung dalam maja labo dahu, serta mengukuhkan budaya malu dalam diri, sebagai cara untuk mengontrol diri, jika sikap dan perilaku mengarah pada perbuatan yang menyimpang, dan penghayatan dari nilai-nilai yang terkandung dalam maja labo dahu tersebut untuk membentuk pribadi peserta didik yang Jurnal Ilmu Sosial dan Pendidikan rendah hati. Jadi pada tahap ini pembinaan yang dilakukan oleh guru profesional dengan cara menyentuh sisi nurani dapat menguatkan karakter religius peserta didik.

\section{Tindakan Moral}

Tahapan penuntunan, dan melatih pembiasan peserta didik, dari pengetahuan moral tentang nilai spiritual, sosial, jujur, disiplin dan tanggung jawab yang terkandung dalam maja labo dahu dan peran pentingnya bagi kehidupan dimasa mendatang, yang disampaikan melalui kegiatan pembelajaran baik dalam kelas maupun di lingkungan sekolah, dalam bentuk tindakan, seperti; membiasakan peserta didik, ikut serta dalam membaca surah yasin secara bersama pada hari jum'at, membiasakan dan menuntun peserta didik untuk sholat dzuhur secara berjamaah sebelum pulang sekolah, mengikutsertakan peserta didik dalam kegiatan pesantren kilat setiap bulan ramadhan, mengikuti kegiatan kepramukaan untuk meningkatkan rasa solidaritas dalam kerja tim, dan lain sebagainya, dilakukan untuk membina tingkah laku supaya ada perubahan sikap kearah yang lebih baik. Sehingga sikap, perilaku dan tindakan yang menjadi kebiasaan peserta didik mencerminkan karakter religius.

Pembinaan karakter religius peserta didik diperlukan pengetahuan moral tentang nilai-nilai kehidupan yang mengarah pada nilai-nilai spritual, agar dapat merubah sikap dan perilaku peserta didik kearah yang lebih baik, seperti halnya yang dilakukan oleh guruguru profesional SDN Sila di Kecamatan Bolo, dengan diberikan pemahaman tentang nilai-nilai lokal yang menujang pembelajaran untuk membina karakter religius peserta didik, sehingga peserta didik memiliki pertimbagan moral yang tinggi dan mampu menghadapi tantangan perubahan zaman yang begitu cepat.

Hasil penelitian Bear end Richards juga mengungkapkan bahwa anak yang memiliki tingkat pertimbangan moral rendah, secara signifikan menunjukan lebih banyak menghadapi problem berperilaku dari pada anak yang memiliki tingkat pertimbangan moral tinggi. Anak yang tingkat pertimbangan moralnya rendah menunjukan tingkat kualitas 
perilaku moral yang negatif lebih tinggi dari pada anak yang memiliki pertimbangan moral yang lebih tinggi, begitupun sebaliknya. Jadi pembinaan karakter religius berbasis nilai kearifan lokal maja labo dahu dapat memberikan tingkat pertimbangan moral tinggi bagi peserta didik SDN Sila di Kecamatan Bolo Kabupaten Bima.

Permasalahan kemerosotan moral yang melanda peserta didik saat ini, bukanlah sepenuhnya datang dari lembaga pendidikan formal yang melibatkan peran penting guru dalam mendampingi dan membina karakter religius peserta didik, sewalaupun terdapat beberapa guru yang kurang melaksanakan pendidikan nilai kepada peserta didik secara persuasif, karena menilai sebahagian kecil peserta didik yang datang ke sekolah sudah bermasalah dari rumahnya. Kemajuan teknologi dan informasi saat ini memasuki era Revolusi Industri 4.0 begitu pesat, sehingga menyebabkan terjadinya globalisasi yang mengakibatkan berubahnya cara manusia berpikir, hidup, dan berhubungan satu dengan yang lain.

Globalisasi akan mengurangi berbagai aktivitas fisik manusia, karena segala sesuatu dapat diperoleh dengan memanfaatkan kemajuan teknologi tanpa dibatasi oleh ruang dan waktu dalam berbagai bidang, tidak hanya dalam bidang teknologi saja, namun juga bidang yang lain seperti ekonomi, sosial, dan politik. Oleh karena terjadinya perubahan tersebut, dapat mempengaruhi kondisi mental, pikiran, sikologis dan tindakan peserta didik dalam mengambil keputusan, ditambah lagi ruang lingkup peserta didik yang tidak dibatasi oleh ruang dan waktu melalui kecanggihan teknologi informasi, akses tentang hal-hal yang dinilai belum pantas untuk anak usia sekolah dasar tidak terkontrol dan di luar pengawasan orang tua. Sehingga pola pikir yang berkembang dalam diri peserta didik cenderung mengikuti apa yang sering dilihat dan diamati, kemudian tampa berpikir panjang diimplementasikan dalam perbuatan sehari-hari.

Perubahan cara pandang, berpikir dan bertindak peserta didik saat ini juga dapat dipahami melalui teori perubahan sosial secara linear dari Max Weber, yang Jurnal Ilmu Sosial dan Pendidikan menyatakan bahwa proses perubahan itu terjadi secara bertahap, dari yang primitif atau sederhana, bila semakin ke depan maka akan lebih moderen dan komprehensif. Hal ini dapat mempengaruhi cara berpikir dan bertindak dalam membangun budaya interaksi antara individu yang satu dengan lainnya. Sehingga berdampak pada pola asuh orang tua terhadap anak-anaknya, karena disibukkan dengan kegiatan ekonomi dan tuntutan zaman, yang mengurangi waktu orang tua untuk mendampingi pendidikan nilai anak yang besumber dari nilai-nilai kearifan lokal budaya. Hal tersebut menjadi salah satu kendala dalam proses penguatan dan pembinaan karakter religius peserta didik yang dilakukan oleh guru dan sekolah karena kurang ditindak lanjuti di rumah oleh orang tua secara mandiri dengan nilai-nilai lokal Bima, khususnya nilai yang cukup familiar di kalangan masyarakat yaitu maja labo dahu

\section{KESIMPULAN}

Pembinaan karakter religius berbasis nilai kearifan lokal maja labo dahu dalam pembelajaran, baik di kelas maupun di lingkungan sekolah, dilaksanakan dengar cara; (1) Membangun percakapan antara guru dengan peserta didik melalui tanya jawab tentang sebuah topik, untuk mewujudkan suasana yang hangat dan akrab, tanpa rasa takut dalam diri peserta didik untuk mengutarakan pendapatnya yang diarahkan pada satu tujuan yang yang hendak dicapai. Sehingga peserta didik dapat memahami secara secara utuh konsep nilai yang disampaikan oleh guru; (2) Guru menceritakan kisah yang inspiratif untuk dihayati oleh peserta didik dengan tujuan untuk membina karakter religiusnya, karena dalam kisah-kisah terdapat berbagai keteladanan dan pendidikan nilai; (3) Perumpamaan yang diberikan oleh guru pada saat pembelajaran dapat memotivasi peserta didik, untuk lebih baik lagi dari sebelumnya, terutama dalam membina karakter religius peserta didik melalui perumpamaan hal-hal yang akan terjadi dimasa mendatang apabila diri tidak diperbaiki hari ini; (4) Guru menjadikan dirinya sebagai teladan bagi peserta didik untuk membina karakter 
religiusnya di sekolah, keteladanan yang diberikan oleh guru pada peserta didik pada umumnya meniru kepribadian guru. Karena kebiasaan peserta didik untuk selalu meniru hal-hal yang ada disekitarnya, dan tidak perduli baik atau buruknya; (5) Guru melakukan pembiasan secara berulang-ulang, tentang konsep nilai dan gagasan yang berguna bagi pembinaan karakter religius peserta didik, agar hal baik yang dilakukan berulang-ulang dapat menjadi kebiasaan peserta didik.

\section{DAFTAR PUSTAKA}

Gunawan. 2017. Pendidikan Karakter (Konsep dan Implementasi). Bandung: Alfabeta.

Khotimah, K. 2016. Model Manajemen Pendidikan Karakter Religius Di SDIT Qurrota A'yun Ponorogo. Muslim Heritage, jurnal.stainponorogo.ac.id/index.php/m uslimheritage vol.1 no. 2, 371-388. Diakses pada Tanggal 19 November 2018.

latifah, Melly,. 2010. Peran Keluarga dalam Pendidikan Karakter Anak. jurnal Sekolah Bakat Prestasi. Wordpres.

Lickona, T. 2013. Pendidikan Karakter: Panduan Lengkap Mendidik Siswa Menjadi Pintar dan Baik. Bandung: Nusa Media.

Moleong, J. 2014. Metodologi Penelitian Kualitatif. Bandung: PT. Remaja Rosdakarya.

Muhaimin, A. M. 2009. Pemikiran Pendidikan Islam. Bandung: Trigenda Karya.

Mujtahid. 2009. Pengembangan Profesi Guru. Malang: UIN-Malang Press

Rukiyati, R., \& Purwastuti, L. A. 2016. Model Pendidikan Karakter Berbasis Kearifan Lokal Pada Sekolah Dasar Di Bantul Yogyakarta. Jurnal Pendidikan Karakter, https://doi.org/10.21831/jpk.v0i1.10743

. Diakses pada Tanggal 20 November 2018

Sudarsana, I. K. 2017. Pengembangan Pendidikan Berbasis Kearifan Lokal Untuk Mewujudkan Toleransi Antar

Jurnal Ilmu Sosial dan Pendidikan
Umat Beragama (hlm. 216-223). Dipresentasikan pada Prosiding Seminar Nasional Filsafat. Diakses Pada Tanggal 22 November 2018.

Shufa, N. K. F. 2018. Pembelajaran Berbasis Kearifan Lokal Di Sekolah Dasar: Sebuah Kerangka Konseptual, vol.1(1), no.

https://jurnal.umk.ac.id/index.php/pend as. Diakses Tanggal 23 November 2018

Suwardani, N. P. 2015. Pewarisan Nilai-Nilai Kearifan Lokal Untuk Memproteksi Masyarakat Bali Dari Dampak Negatif Globalisasi. Journal of Bali Studies, $5(2)$.

Tajib, H. A. 1995. Sejarah Bima Dana Mbojo. Jakarta: Harapan Masa PGRI Jakarta.

Wibowo, A. 2015. Pendidikan Karakter Berbasis Kearifan Lokal Di Sekolah (Cetakan Ke-1). Yogyakarta: Pustaka Pelajar.

Widiastuti, H. 2016. Peran Guru Dalam Membentuk Siswa Berkarakter, 13.Studi PGSD FKIP Universitas Muhammadiyah Surakarta. Diakses Tanggal 23 November 2018.

Yusutria, M. 2017. Profesionalisme Guru Dalam Meningkatkan Kualitas Sumber Daya Manusia. Curricula: Journal of Teaching and Learning, 2(1). Diakses pada Tanggal 20 November 2018

Zubaedi, D. P. K. 2011. Desain Pendidikan Karakter (Konsep dan Aplikasi dalam Lembaga Pendidikan). Jakarta: Kencana. 